\title{
PEMBELAJARAN KOOPERATIF TIPE MAKE A MATCH TERHADAP HASIL BELAJAR
}

\author{
Ulfatrianti Amin ${ }^{1 *}$, Ramlawati ${ }^{1}$, Ratnawaty Maming ${ }^{1}$ \\ ${ }^{1}$ Program Studi Pendidikan IPA Fakultas Matematika dan Ilmu Pengetahuan Alam, Universitas Negeri Makassar \\ Email: ulfatriantiamin@gmail.com
}

\begin{abstract}
Abstrak
Penelitian ini bertujuan untuk mengetahui peningkatan hasil belajar peserta didik dengan model pembelajaran Kooperatif Tipe Make A Match pada materi Klasifikasi Makhluk Hidup. Jenis penelitian ini adalah penelitian eksperimen semu dimana tidak mengontrol semua variable yang relevan dan dilakukan dua kelas satu kelas eksperimen dan satu kelas kontrol. Populasi penelitian ini adalah seluruh peserta didik kelas VII SMPN 2 Tapalang sebanyak 4 kelas dengan sampel adalah kelas VII D sebagai kelas kontrol dengan jumlah peserta didik 23 orang. Dengan kelas VII C sebagai kelas eksperimen dengan jumlah peserta didik 22 orang. Variabel bebas dalam penelitian ini adalah metode kooperatif tipe Make A Match dan metode konvensional, sedangkan variabel terikatnya adalah hasil belajar peserta didik pada materi klasifikasi makhluk hidup. Data dianalisis dengan menggunakan analisis statistik deskriptif dan inferensial. Hasil analisis statistik deskriptif diperoleh rata-rata skor 14.22 pada kelas eksperimen yang termasuk dalam kategori sedang, pada kelas kontrol diperoleh rata-rata skor 9.78 rendah. Selain itu, peningkatan hasil belajar peserta didik diperoleh nilai N-Gain sebesar 0.50 untuk kelas eksperimen dengan kategori sedang, dan nilai N-Gain sebesar 0.27 untuk kelas kontrol dengan kategori rendah. Maka terdapat pengaruh positif terhadap hasil belajar peserta didik kelas kelas VII SMP Negeri 2 Tapalang pada materi pokok Klasifikasi Makhluk Hidup.
\end{abstract}

Kata kunci: Make A Match, Hasil Belajar, Klasifikasi Makhluk Hidup

\begin{abstract}
This study aims to the improvement of student learning outcomes with the Make A Match Cooperative Learning model in the Classification of Living Things. This type of research is a quasi-experimental research where it does not control all relevant variables and is carried out in two first-class classes. Experiment and one control class. The population of this study were all students of class VII SMPN 2 Tapalang as many as 4 classes with the sample being class VII D as the control class with 23 students. With class VII C as the experimental class with 22 students. The independent variable in this study is the Make A Match cooperative method and the conventional method, while the dependent variable is the learning outcomes of students on the classification of living things. Data analysis used descriptive and inferential statistical analysis. The results of the descriptive statistical analysis obtained an average score of 14.22 in the experimental class which was included in the medium category, in the control class the average score was 9.78 which was low. In addition, the increase in student learning outcomes obtained an $\mathrm{N}$-Gain value of 0.50 for the experimental class with the moderate category, and an $\mathrm{N}$-Gain value of 0.27 for the control class with the low category. So there is a positive influence on the learning outcomes of class VII students of SMP Negeri 2 Tapalang on the subject matter of the Classification of Living Things.

Keywords: Make A Match, Learning Outcomes, Classification of Living Things
\end{abstract}




\section{PENDAHULUAN}

IImu pengetahuan alam

berhubungan dengan cara mencari tahu tentang alam secara sistematis, sehingga IPA bukan hanya penguasaan kumpulan pengetahuan yang berupa fakta-fakta, konsep-konsep, atau prinsip-prinsip saja tetapi juga merupakan suatu proses penemuan. Proses pembelajaran IPA menekankan pada pemberian pengalaman langsung untuk mengembangkan kompetensi agar menjelajahi dan memahami alam sekitar secara ilmiah. Kenyataan yang terjadi di lapangan, guru cenderung dominan dalam mengajarkan konsep atau materi pelajaran di kelas sehingga peserta didik semakin tergantung pada inisiatif guru. Dalam hal ini semua kegiatan di kelas berpusat pada guru, apabila keadaan ini berlangsung secara terus menerus, maka upaya meningkatkan kualitas pembelajaran tidak akan mengalami perubahan.

Metode, model, dan media pembelajaran merupakan unsur-unsur yang sangat penting dalam proses pembelajaran. Model dan media pembelajaran akan mengarahkan guru dalam merancang pembelajaran di kelas, sehingga dapat membantu peserta didik dalam mencapai tujuan pembelajaran yang telah diciptakan. Namun demikian terdapat beberapa faktor yang dapat menghambat dan mengganggu kemajuan belajar peserta didik, sehingga dalam proses pembelajaran perlu menerapkan model pembelajaran yang tepat sehingga dapat membawa dampak positif dalam menciptakan proses pembelajaran yang berkualitas dan hasil belajar yang optimal sehingga berujung pada perbaikan kualitas pendidikan yang lebih baik.

Berdasarkan hasil wawancara dengan
Guru IPA di SMP Negeri 2 Tapalang diperoleh informasi bahwa hasil belajar peserta didik masih rendah, diakibatkan karena peserta didik kurang berpartisipasi pada saat proses belajar mengajar. Sudah terbukti bahwa pada saat observasi yang telah dilakukan di kelas VII SMP Negeri 2 Tapalang, pada saat proses belajar mengajar tersebut memang peserta didik terlihat bosan dalam menerima materi, kurang semangat dalam belajar, kurangnya keaktifan peserta didik dalam proses yang ditunjukkan dengan kurangnya pertanyaan maupun disampaikan ke peserta didik.

Melihat permasalahan di atas, maka perlu ada upaya bagaimana cara menyampaikan pelajaran IPA yang tepat sehingga dapat meningkatkan hasil belajar peserta didik. Oleh karena itu, upaya dalam meningkatkan hasil belajar peserta didik kelas VII SMP Negeri 2 Tapalang perlu mengemas materi IPA dalam suatu pembelajaran yang aktif dan menyenangkan, sehingga mampu melibatkan peserta didik dalam aktivitas pembelajaran secara penuh agar peserta didik lebih mudah memahami pelajaran yang diberikan. Adapun salah satu model yang tepat untuk diterapkan adalah model pembelajaran kooperatif tipe Make $A$ Match. Model pembelajaran Make A Match atau mencari pasangan merupakan salah satu alternative yang dapat diterapkan kepada peserta didik. Penerapan metode ini dimulai dari teknik yang peserta didik disuruh mencari pasangan kartu yang merupakan jawaban atau soal sebelum batas waktunya, peserta didik yang dapat mencocokkan kartunya diberi poin (Suprijono, 2009).

Berdasarkan uraian di atas, maka tujuan penelitian ini adalah untuk mengetahui peningkatan hasil belajar 
peserta didik yang dibelajarkan dengan model pembelajaran Kooperatif Tipe Make A Match pada kelas VII SMP Negeri Tapalang pada pokok materi Klasifikasi Makhluk Hidup.

Sejalan dengan penelitian yang dilakukan oleh (Fatimatuzzahro, 2015), hasil penelitian yang dilakukan menunjukkan bahwa ada perbedaan yang signifikan antara hasil belajar IPA peserta didik menggunakan model Cooperative Learning tipe Make A Match dengan model yang biasa digunakan di SMP Muhammadiyah 9 Yogyakarta. Rekapitulasi nilai hasil belajar IPA peserta didik menunjukkan bahwa peserta didik mendapatkan pelajaran dengan menggunakan model cooperative tipe Make A Match lebih tinggi dibanding dengan menggunakan model yang biasa digunakan. Sehingga model Cooperative Learning tipe Make A Match lebih baik digunakan. Pembelajaran IPA akan lebih menarik jika digunakan model pembelajaran Make A Match sebab dalam mempelajari materi tersebut, peserta didik tidak terpaku pada hafalan yang sifatnya sesaat dan dapat membantu peserta didik dalam mengingat materi-materi yang telah diajarkan sebelumnya. Dengan begitu diharapkan peserta didik dapat meningkatkan hasil belajarnya.

\section{METODE}

Desain penelitian yang digunakan adalah "Nonequivalent Control Group Design" merupakan penelitian yang dilakukan dengan melibatkan dua kelompok belajar yang dimana kelompok satu diberikan perlakuan (kelompok eksperimen) dan kelompok kedua tidak diberikan perlakuan (kelas kontrol) (Sugiyono, 2017). Desain penelitian tersebut dapat dilihat pada Tabel 1.
Tabel 1. Nonequivalent Pretest-Posttest Control Group Design

\begin{tabular}{lccc}
\hline Kelompok & Pretest & Perlakuan & $\begin{array}{c}\text { Post } \\
\text { test }\end{array}$ \\
\hline Eksperimen & $\mathrm{O}_{1}$ & $\mathrm{X}$ & $\mathrm{O}_{2}$ \\
Kontrol & $\mathrm{O}_{3}$ & - & $\mathrm{O}_{4}$ \\
\hline & & (Sugiyono, 2017).
\end{tabular}

Keterangan:

$X$ : Perlakuan dengan menggunakan tipe Make A Match

$\mathrm{O}_{1}$ dan $\mathrm{O}_{3}$ : Tes awal (Pretest) untuk kelas eksperimen dan kelas kontrol

$\mathrm{O}_{2}$ dan $\mathrm{O}_{4}$ : Tes akhir (Postest) untuk kelas eksperimen dan kelas kontrol

Populasi penelitian yaitu seluruh peserta didik kelas VII SMP Negeri 2 Tapalang Tahun pelajaran 2019/ 2020 yang terdiri dari 4 kelas dengan jumlah peserta didik 104 orang dan pemilihan sampel dilakukan dengan cara purposive sampling, yaitu pengambilan sampel dilakukan secara sengaja sesuai tujuan peneliti dengan persyaratan sampel yang diperlukan dan terpilihlah kelas VII D sebagai kelas kontrol yang diajar dengan menggunakan model pembelajaran konvensional dan kelas VIIC sebagai kelas eksperimen yang diajar dengan model pembelajaran kooperatif tipe Make A Match dengan ketentuan semua kelas dianggap homogen. Jumlah sampel masing-masing yaitu kelas kontrol (23) orang dan kelas eksperimen (22) orang.

Instrumen yang digunakan dalam penelitian ini adalah tes hasil belajar dalam bentuk tes objektif berupa soal pilihan ganda sebanyak 20 nomor yang terdiri dari empat pilihan jawaban yang didasarkan pada aspek kognitif meliputi jenjang mengingat (C1) dengan skor 1 , memahami (C2) dengan skor 1, dan mengaplikasikan (C3) dengan skor 1. Penyusunan instrumen tes ini, terlebih dahulu dibuat kisi-kisi yang 
didalamnya mencakup nomor soal, butir soal dan indikator tes hasil belajar.

Data yang diperoleh dari sampel penelitian ini berupa data kuantitatif skor hasil belajar peserta didik yang kemudian diolah dengan statistik deskriptif dan statistik inferensial. Statistik deskriptif digunakan untuk mendeskripsikan tingkat hasil belajar yang diperoleh peserta didik. Hal ini dimaksudkan untuk mengetahui skor rata-rata, standar deviasi, varians, skor maksimum, skor minimum dan distribusi frekuensi.

Skor hasil belajar kemudian dianalisis dengan $\mathrm{N}$-gain untuk melihat peningkatan dari pretest dan posttest. $\mathrm{N}$ gain adalah perbandingan skor posttest dengan selisih skor maksimum pretest. $\mathrm{N}$ gain disebut juga skor ternormalisasi.

$N-$ gain $=\frac{S_{\text {post }}-S_{\text {pre }}}{S_{\text {maks }}-S_{\text {pre }}}$

Peningkatan hasil belajar dapat dilihat dari tingkat perolehan $\mathrm{N}$-gain yang terdapat tiga kategori, yaitu:

Tabel 2. Kategori Tingkat $\mathbf{N}$-gain

\begin{tabular}{lc}
\hline \multicolumn{1}{c}{ Batasan } & Kategori \\
\hline$N$-gain $<0,3$ & Rendah \\
$0,3 \leq N$-gain $<0,7$ & Sedang \\
$N$-gain $\geq 0,7$ & Tinggi \\
\hline
\end{tabular}

Sedangkan statistik inferensial digunakan untuk menguji hipotesis penelitian. Sebelum melakukan uji hipotesis (Uji t), terlebih dahulu dilakukan uji prasyarat analisis berupa uji normalitas dengan chi-kuadrat dan uji homogenitas dengan uji Fisher. Data dalam penelitian ini di analisis dengan bantuan Microsoft Excel 2013. Uji normalitas dilakukan untuk mengetahui sampel yang dipakai berdistribusi normal atau tidak. Pengujian normalitas digunakan rumus Chi-Kuadrat, yaitu:
$X^{2}=\sum \frac{\left(f_{o}-f_{e}\right)^{2}}{f_{e}}$

Uji homogenitas digunakan untuk menunjukkan bahwa kelas-kelas dalam populasi memiliki homogenitas yang sama. Rumus yang digunakan adalah uji Fisher, yaitu:

$\mathrm{F}=\frac{\text { Varians terbesar }}{\text { Varians terkecil }}$

(Sugiyono, 2016).

\section{HASIL DAN PEMBAHASAN}

Hasil analisis statistik deskriptif menunjukkan deskripsi tentang karakteristik distribusi nilai tes hasil belajar dari masing-masing kelompok penelitian.

Tabel 3. Hasil Analisis Statistik Deskriptif Skor Pretest dan Posttest Peserta Didik Kelas Eksperimen dan Kelas Kontrol

\begin{tabular}{clcccc}
\hline No. & Statistik & \multicolumn{2}{c}{ Kelas Eksperimen } & \multicolumn{2}{c}{ Kelas Kontrol } \\
& Pretest & Posttest & Pretest & Posttest \\
\hline 1. & $\begin{array}{l}\text { Jumlah } \\
\text { sampel }\end{array}$ & 22,00 & 22,00 & 23,00 & 23,00 \\
2. & $\begin{array}{l}\text { Skor } \\
\text { tertinggi }\end{array}$ & 13.00 & 17,00 & 9,00 & 17,00 \\
3. $\quad \begin{array}{l}\text { Skor } \\
\text { terendah }\end{array}$ & 3,00 & 11,00 & 2,00 & 5,00 \\
4. $\quad \begin{array}{l}\text { Skor rata- } \\
\text { rata }\end{array}$ & 8.04 & 14.22 & 6,00 & 9.78 \\
5. $\quad \begin{array}{l}\text { Standar } \\
\text { deviasi }\end{array}$ & 2.88 & 2.46 & 2.31 & 2.85 \\
6. & Varians & 8.33 & 6.88 & 5.36 & 8.77 \\
\hline
\end{tabular}

Berdasarkan Tabel 3 diperoleh bahwa nilai hasil belajar IPA pada materi sistem pencernaan manusia kelas eksperimen yang diajar menggunakan model pembelajaran kooperatif tipe make a match dan kelas kontrol yang diajarkan dengan pembelajaran konvensional terdapat perbedaan.

Setelah diperoleh nilai pretest dan posttest dari kedua kelas penelitian, dapat 
dilakukan uji $\mathrm{N}$-gain untuk mengetahui peningkatan hasil belajar IPA peserta didik seperti pada Tabel 4.

Tabel 4. Rata-rata skor N-Gain Tes Hasil Belajar Kelas Eksperimen dan Kelas Kontrol

\begin{tabular}{|c|c|c|c|c|}
\hline \multirow[b]{2}{*}{ Kelas } & \multicolumn{2}{|c|}{ Skor } & \multirow{2}{*}{$\begin{array}{c}\text { Rata- } \\
\text { Rata } \\
\text { Skor N- } \\
\text { Gain }\end{array}$} & \multirow[t]{2}{*}{ Ketegori } \\
\hline & $\begin{array}{l}\text { Pre } \\
\text { test }\end{array}$ & $\begin{array}{c}\text { Post } \\
\text { test }\end{array}$ & & \\
\hline $\begin{array}{c}\text { Kelas } \\
\text { Eksperimen }\end{array}$ & 8.04 & 14.22 & 0.50 & Sedang \\
\hline $\begin{array}{c}\text { Kelas } \\
\text { Kontrol }\end{array}$ & 6.00 & 9.78 & 0.27 & Rendah \\
\hline
\end{tabular}

Tabel 4 menunjukkan bahwa skor $N$ gain hasil belajar peserta didik kategori kelas eksperimen termasuk dalam kategori sedang dengan skor $N$-Gain 0,50. Sedangkan, skor $\mathrm{N}$-gain hasil belajar peserta didik pada kelas kontrol termasuk dalam kategori rendah dengan skor N-Gain 0,27.

Pemahaman peserta didik pada materi klasifikasi makhluk hidup pada kelas eksperimen dan kelas kontrol dapat dilihat dari presentase pencapaian tiap indikatornya. Ada 7 indikator yang harus dicapai peserta didik dalam materi klasifikasi makhluk hidup, dimana pada indikator 1 diwakili oleh 3 soal, indikator 2 diwakili oleh 2 soal, indikator 3 diwakili oleh 3 soal, indikator 4 diwakili oleh 32 soal, indikator 5 diwakili oleh 4 soal, indikator 6 diwakili 3 soal, dan indikator 7 diwakili 3 soal. Jenjang kemampuan kognitif yang dipakai yaitu C1 (mengingat), C2 (memahami), dan C3 (menerapkan). Berikut disajikan tabel persentase pencapaian tiap indikator kelas eksperimen dan kelas kontrol pada materi klasifikasi makhluk hidup. Pencapaian tiap indikator kelas eksperimen dan kelas kontrol pada Tabel 5.
Tabel 5. N-gain dengan Kategori Tiap Indikator Kelompok Eksperimen

\begin{tabular}{|c|c|c|c|c|c|c|}
\hline No & Indikator & $\begin{array}{c}\text { Jumlah } \\
\text { soal }\end{array}$ & $\begin{array}{c}\text { Prete } \\
\text { st }\end{array}$ & $\begin{array}{c}\text { Postt } \\
\text { est }\end{array}$ & $\begin{array}{c}\mathrm{N}- \\
\text { gain }\end{array}$ & Kategori \\
\hline 1. & $\begin{array}{l}\text { Menjelaskan } \\
\text { ciri-ciri makhluk } \\
\text { hidup dan } \\
\text { benda tak } \\
\text { hidup }\end{array}$ & 3 & 25 & 61 & 0.88 & Tinggi \\
\hline 2. & $\begin{array}{l}\text { Memberi } \\
\text { contoh } \\
\text { makhluk } \\
\text { hidup dan } \\
\text { benda } \\
\text { dikehidupan } \\
\text { sehari-hari }\end{array}$ & 2 & 24 & 33 & 0.45 & Sedang \\
\hline 3. & $\begin{array}{l}\text { Memahami } \\
\text { klasifikasi } \\
\text { makhluk } \\
\text { hidup }\end{array}$ & 3 & 26 & 44 & 0.45 & Sedang \\
\hline 4. & $\begin{array}{l}\text { Mengetahui } \\
\text { tingkatan } \\
\text { takson } \\
\text { klasifikasi } \\
\text { makhluk } \\
\text { hidup }\end{array}$ & 2 & 19 & 25 & 0.24 & Rendah \\
\hline 5. & $\begin{array}{l}\text { Menjelaskan } \\
\text { klasifikasi } \\
\text { makhluk } \\
\text { hidup } 5 \\
\text { kingdom } \\
\text { (Monera, } \\
\text { Fungi,, dan } \\
\text { Protista) }\end{array}$ & 4 & 33 & 58 & 0.45 & Sedang \\
\hline 6. & $\begin{array}{l}\text { Mengklasifika } \\
\text { sikan makhluk } \\
\text { hidup }\end{array}$ & 3 & 27 & 39 & 0.31 & Sedang \\
\hline 7. & $\begin{array}{l}\text { Mengklasifika } \\
\text { si makhluk } \\
\text { hidup } \\
\text { berdasarkan } \\
\text { kingdom } \\
\text { animalia }\end{array}$ & 3 & 23 & 53 & 0.70 & Sedang \\
\hline
\end{tabular}

Tabel 5 terlihat bahwa terdapat perbedaan peningkatan indikator hasil belajar peserta didik pada kelas eksperimen. Peningkatan indikator yang paling tinggi pada kelas eksperimen adalah pada indikator ke 1 mengenai menjelaskan ciri-ciri makhluk hidup dan benda tak hidup dan Peningkatan indikator yang paling rendah pada kelas eksperimen adalah indikator 4 tentang Mengetahui tingkatan takson klasifikasi makhluk hidup. 
Tabel 6. $\mathbf{N}$-gain dengan Kategiri Tiap Indikator Kelompok Kontrol

\begin{tabular}{|c|c|c|c|c|c|c|}
\hline $\begin{array}{l}\mathbf{N} \\
\mathbf{0}\end{array}$ & Indikator & $\begin{array}{l}\text { Jumla } \\
\text { h soal }\end{array}$ & $\begin{array}{c}\text { Prete } \\
\text { st }\end{array}$ & $\begin{array}{c}\text { Post } \\
\text { test }\end{array}$ & $\begin{array}{c}\mathrm{N}- \\
\text { gai } \\
n\end{array}$ & Kategori \\
\hline 1. & $\begin{array}{l}\text { Menjelaskan } \\
\text { ciri-ciri } \\
\text { makhluk } \\
\text { hidup dan } \\
\text { benda tak } \\
\text { hidup }\end{array}$ & 3 & 24 & 46 & $\begin{array}{c}0.4 \\
9\end{array}$ & Sedang \\
\hline 2. & $\begin{array}{l}\text { Memberi } \\
\text { contoh } \\
\text { makhluk } \\
\text { hidup dan } \\
\text { benda } \\
\text { dikehidupan } \\
\text { sehari-hari }\end{array}$ & 2 & 28 & 34 & $\begin{array}{c}0.3 \\
3\end{array}$ & Sedang \\
\hline 3. & $\begin{array}{l}\text { Memahami } \\
\text { klasifikasi } \\
\text { makhluk } \\
\text { hidup }\end{array}$ & 3 & 19 & 22 & $\begin{array}{c}0.0 \\
6\end{array}$ & Rendah \\
\hline 4. & $\begin{array}{l}\text { Mengetahui } \\
\text { tingkatan } \\
\text { takson } \\
\text { klasifikasi } \\
\text { makhluk } \\
\text { hidup }\end{array}$ & 2 & 13 & 14 & $\begin{array}{c}0.0 \\
3\end{array}$ & Rendah \\
\hline 5. & $\begin{array}{l}\text { Menjelaska } \\
\text { n klasifikasi } \\
\text { makhluk } \\
\text { hidup } 5 \\
\text { kingdom } \\
\text { (Monera, } \\
\text { Fungi,, dan } \\
\text { Protista) }\end{array}$ & 4 & 16 & 26 & $\begin{array}{c}0.1 \\
3\end{array}$ & Rendah \\
\hline 6. & $\begin{array}{l}\text { Mengklasifik } \\
\text { asikan } \\
\text { makhluk } \\
\text { hidup }\end{array}$ & 3 & 16 & 33 & $\begin{array}{c}0.3 \\
2\end{array}$ & Sedang \\
\hline 7. & $\begin{array}{l}\text { Mengklasifik } \\
\text { asi makhluk } \\
\text { hidup } \\
\text { berdasarkan } \\
\text { kingdom } \\
\text { animalia }\end{array}$ & 3 & 15 & 42 & $\begin{array}{c}0.5 \\
0\end{array}$ & Sedang \\
\hline
\end{tabular}

Berdasarkan data yang terlihat pada Tabel 6 bahwa peningkatan indikator yang paling tinggi pada kelas kontrol yaitu 1. Peningkatan indikator yang paling rendah pada kelas kontrol adalah indikator 4 tentang Mengetahui tingkatan takson klasifikasi makhluk hidup.
Hasil uji normalitas data hasil belajar pre test peserta didik di peroleh nilai

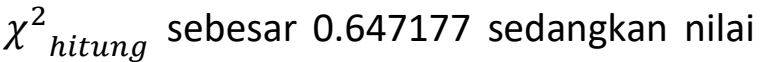
$\chi_{\text {tabel }}^{2}$ pada taraf signifikan $(\alpha)=0,05$ dan derajat kebebasan $(\mathrm{dk})=\mathrm{k}-1=5-1=4$, diperoleh $\quad \chi_{(1-\alpha)(d k)}^{2}=\chi_{(0,95)(5)}^{2}=$ 11,0705. Berdasarkan hasil analisis data tersebut dinyatakan bahwa $\chi_{\text {hitung }}^{2}<\chi_{\text {tabel }}^{2}$ yaitu $0.647177<11,0705$ maka dapat disimpulkan data pada kelas eksperimen berdistribusi normal. Sedangkan kelas kontrol, hasil uji normalitas data hasil belajar peserta didik diperoleh nilai $\chi_{\text {hitung }}^{2}$ sebesar 10,83445 . Sedangkan nilai $\chi_{\text {tabel }}^{2}$ pada taraf signifikan $(\alpha)=0,05$ dan derajat kebebasan $(\mathrm{dk})=\mathrm{k}-1=5-1=$ 4, diperoleh $\chi_{(1-\alpha)(d k)}^{2}=$ $\chi_{(0,95)(4)}^{2}=11,070$. Berdasarkan hasil analisis data tersebut dinyatakan bahwa $\chi_{\text {hitung }}^{2}<\chi_{\text {tabel }}^{2}$ yaitu 10,4708 $<11,070$ maka dapat disimpulkan data pada kelas kontrol berdistribusi normal.

Setelah kedua sampel dinyatakan terdistribusi normal, maka dilakukan uji homogenitas menggunakan skor $\mathrm{N}$-gain. Tujuan dari dilakukannya uji homogenitas untuk mengetahui apakah data dalam penelitian ini memiliki varians yang sama (homogen) atau tidak (heterogen). Setelah dilakukan pengolahan data, maka untuk pengujian homogenitas varian akan diperoleh skor hitung. Hasil pengujian menggunakan skor $\mathrm{N}$-gain maka di peroleh $F_{\text {hitung }}<F_{\text {tabel }}$ yaitu $2,3<4,32$ dengan demikian bahwa varians data kedua kelompok tersebut dinyatakan sama (homogen).

Berdasarkan pengujian hipotesis dengan menggunakan uji-t yang lebih detailnya dapat dilihat pada lampiran 
analisis Inferensial. Hasil analisis diperoleh $t_{\text {hitung }}=3,38033>t_{\text {tabel }}=1,68107$. Hal ini berarti $H_{0}$ ditolak dan $H_{1}$ diterima. Sehingga dapat disimpulkan bahwa model pembelajaran kooperatif tipe Make $A$ Match berpengaruh signifikan terhadap hasil belajar peserta didik kelas VII SMP Negeri 2 Tapalang pada materi pokok klasifikasi makhluk hidup.

Berdasarkan hasil penelitian yang telah dilakukan pada materi pokok klasifikasi makhluk hidup menunjukkan bahwa hasil belajar peserta didik yang diajar dengan menggunakan model pembelajaran kooperatif tipe Make A Match lebih tinggi dibandingkan dengan hasil belajar peserta didik yang diajar dengan model pembelajaran langsung. Hal ini disebabkan oleh karena pembelajaran kooperatif tipe Make A Match melatih dan membiasakan peserta didik untuk bekerjasama, saling berbagi pengetahuan, pengalaman, tugas, dan tanggung jawab. Sehingga, peserta didik akan lebih mudah membangun pengetahuan dan pemahaman konsep yang sulit jika di diskusikan dengan teman sebayanya. Ditinjau dari analisis statistik deskriptif dan inferensial, hasil analisis statistik deskriptif kelas eksperimen diperoleh yang diajar menggunakan pembelajaran kooperatif tipe Make $A$ Match tergolong dalam kategori sedang dengan skor rata-rata $N$-gain 0,50 dan untuk kelas kontrol yang diajar menggunakan model pembelajaran langsung tergolong dalam kategori sedang dengan skor rata-rata $N$-gain 0.27 .

Faktor yang mempengaruhi skor hasil belajar peserta didik pada kelas eksperimen yang tergolong tinggi dibandingkan dengan kelas kontrol karena adanya aktivitas dan interaksi diantara peserta didik melalui kerja sama dalam kelompok untuk saling memotivasi dan saling membantu dalam menguasai materi pelajaran guna mencapai prestasi yang lebih maksimal, tanpa mengesampingkan peran pendidik.

Pencapaian indikator hasil belajar kelas eksperimen berada pada kategori sedang ditinjau dari keseluruhan indikator yang berjumlah tujuh terdapat satu indikator dikategorikan tinggi dan 5 indikator dikategorikan sedang. Hal ini disebabkan oleh partisipasi aktif peserta didik dalam berdiskusi. Sehingga, peserta didik lebih mudah membangun pengetahuan dan pemahaman konsep yang sulit, sedangkan untuk kelas kontrol dapat dikategorikan sedang karena hanya 4 indikator yang berada pada kategori sedang. Hal ini disebabkan karena kurangnya partisipasi aktif peserta didik dalam berdiskusi dan berbagi pengetahuan antar anggota kelompoknya selain itu soal pada indikator 1 terbilang mudah dan berada pada ranah kognitif (C1). Sedangkan indikator 2-7 berada pada kategori sedang karena tingkat kesulitan soalnya bervariasi yaitu mulai dari ranah kognitif C2-C3.

Pada kelas eksperimen peserta didik terlibat aktif dalam proses pembelajaran, terutama dalam mengerjakan LKPD peserta didik telihat tertarik mengerjakannya. Selama proses berlangsung peserta didik memahami sendiri konsep materi pelajaran pada LKPD. LKPD dalam model pembelajaran kooperatif tipe Make $A$ Match dikelas mampu menarik perhatian peserta didik. Selain itu LKPD yang berisikan wacana tersebut dapat memberikan motivasi dan informasi kepada peserta didik dalam kegiatan belajar sehingga dengan mudah memahami materi. Hal ini didukung oleh teori yang dikemukakan oleh Isjoni (2010), bahwa keunggulan penggunaan model pembelajaran kooperatif tipe Make 
A Match adalah memacu keinginan peserta didik untuk mengetahui, memotivasi mereka untuk melanjutkan pekerjaan sehingga mereka menemukan jawaban dan peserta didik belajar menemukan masalah secara mandiri. Manfaat yang diperoleh bagi peserta didik dalam pembelajaran kooperatif tipe Make A Match adalah peserta didik akan memahami konsepkonsep dasar dan ide-ide lebih baik, membantu dalam menggunakan daya ingat dan transfer pada situasi-situasi proses belajar yang baru dan mampu mengembangkan kemampuan berpikir peserta didik dan dapat meningkatkan hasil belajar peserta didik.

Keyakinan akan keunggulan dan keuntungan kooperatif dalam pembelajaran IPA yang mengajar dengan model pembelajaran kooperatif tipe Make $A$ Match adalah : (1) peserta didik akan memahami konsep-konsep dasar dan ideide yang lebih baik; (2) membantu peserta didik dalam menggunakan daya ingat dan transfer pada situasi-situasi proses belajar yang baru; (3) mendorong peserta didik untuk berpikir dan bekerja atas inisiatif sendiri; dan (4) mendorong peserta didik berpikir inisiatif dan merumuskan hipotesanya sendiri (Isjoni, 2010). Sama dengan proses pembelajaran pada kelas kontrol, peserta didik juga diberikan perlakuan dalam mengerjakan LKPD akan tetapi hanya guru yang menjadi sumber pembelajaran. Dimana guru hanya berperan sebagai pengarah dalam membangun potensi peserta didik sedangkan peserta didik sebagai pusat pembelajaran.

Memperkuat hasil analisis deskriptif, maka dilakukan analisis statistik inferensial untuk membuktikan hipotesis yang diajukan dengan menggunakan statistik uji-t. Sebelum digunakan uji-t, terlebih dahulu di lakukan uji normalitas dan homogenitas. Uji normalitas data digunakan untuk menguji kenormalan data skor sedangkan uji homogenitas digunakan untuk menguji apakah homogen atau tidak. Data dapat dikatan homogen apabila $x^{2}$ hitung lebih kecil daripada $x^{2}$ tabel. Hasil uji normalitas kelas eksperimen dan kelas kontrol $x^{2}$ hitung lebih kecil daripada $x^{2}$ tabel. Berdasarkan hasil uji homogenitas data $x^{2}$ hitung lebih kecil daripada $x^{2}$ tabel untuk kedua kelas (kelas eksperimen dan kelas kontrol) hal ini berarti data untuk kelas eksperimen dan kontrol terdistribusi normal.

Hasil analisis inferensial dengan menggunakan uji-t diperoleh skor $t_{\text {hitung }}$ sebesar 3,38033 lebih tinggi daripada skor tabel yakni 1,68107. Hal ini berarti $H_{0}$ ditolak dan $H_{1}$ diterima. Sehingga dapat disimpulkan bahwa Model pembelajaran kooperatif tipe Make A Match berpengaruh positif terhadap hasil belajar peserta didik kelas VII SMPN 2 Tapalang pada materi klasifikasi makhluk hidup. Hal ini sesuai dengan penelitian sebelumnya yang dilakukan oleh Fatimatuzzahro (2015) yang juga menunjukkan bahwa pengaruh model pembelajaran kooperatif tipe Make $A$ Match dapat meningkatkan hasil belajar peserta didik. Penelitian yang dilakukan dapat membuktikan bahwa penggunaan model pembelajaran kooperatif tipe Make A Match berpengaruh positif terhadap hasil belajar peserta didik. Hal tersebut dikarenakan sesuai prosedur pelaksanaan mulai dari observasi, pelaksanaan dan pengolahan data.

Sejalan dengan penelitian yang dilakukan oleh (Yunus, Sudarto, \& Takdir, 2018), Pengujian hipotesis penelitian dilakukan dengan menggunakan uji-t. Hasil analisis data diperoleh nilai thitung $=2,13$ dan nilai ttabel pada taraf signifikan $(\alpha)=$ 
0,05 dan $\mathrm{db}=38$, ttabel $(0,05)(38)=1,68$. Data ini menunjukkan bahwa nilai thitung $=$ 2,13 $>$ ttabel $=1,68$ yang artinya hipotesis (Ho) ditolak dan hipotesis ( $\mathrm{Ha}$ ) diterima. Sehingga dapat disimpulkan bahwa terdapat pengaruh positif model pembelajaran kooperatif tipe Make $A$ Match terhadap hasil belajar peserta didik kelas VII SMP Negeri 4 Kahu pada materi ekosistem.

\section{PENUTUP}

\section{Simpulan}

Berdasarkan hasil analisis data dan pembahasan maka dapat disimpulkan bahwa hasil belajar peserta didik kelas VII SMP Negeri 2 Tapalang dengan menerapkan model pembelajaran kooperatif tipe Make A Match pada materi pokok klasifikasi makhluk hidup berada pada kategori sedang.

\section{DAFTAR PUSTAKA}

Fatimatuzzahro, Subiki, \& Wahyuni, S. (2015). Penerapan Model Cooperative Learning dengan Teknik Make A Match Terhadap Keterampilan Proses Sains dan Hasil Belajar Siswa pada Pembelajaran IPA di SMP . Jurnal Pendidikan Fisika, Vol. 4 No.2,, 150.

Hake, R. R. (1999). Analyzing Change, Gain Score. Http://www.physich.indiana. edu/.

Isjoni. (2010). Cooperative Learning. Bandung: Alfabeta.

Iwan, \& Lestari, N. P. (2015). Penerapan Model Pembelajaran Kooperatif Tipe Make A Match untuk Meningkatkan
Motivasi dan Hasil Belajar Biologi pada Materi Ekosistem. Jurnal Nalar Pendidikan Volume 3, Nomor 2,, 8081.

Mikran, Pasaribu, M., \& Darmadi, I. W. (2013). Penerapan Model Pembelajaran Kooperatif Make A Match untuk Meningkatkan Hasil Belajar Siswa Kelas VIIA SMP Negeri 1 Tomini Pada Konsep Gerak . Jurnal Pendidikan Fisika Tadulako (JPFT) Vol. 2 No. 2 , 11.

Mun'im, A., Sudarto, \& Mahfud, M. (2018). Pengaruh Penggunaan Model Pembelajaran Kooperatif berbasis Kontekstual Terhadap Hasil Belajar Peserta Didik (Studi Pada Materi Pokok Interaksi Makhluk Hidup Dengan Lingkungan). JIT Vol 1. No 2.

Permendikbud. (2014). Penilaian Hasil Belajar oleh Pendidik pada Pendidikan Menengah. Jakarta: Menteri Pendidikan dan Kebudayaan Republik Indonesia.

Riadi, S. (2016). Statistika Penelitian (Analisis Manual dan IBM SPSS). Yogyakarta: CV Andi Offset.

Rusman. (2016). Model-model Pembelajaran: Pengembangan Profesionalisme Guru. Jakarta: PT RajaGrafindo Persada.

Sugiyono. (2016). Metode Penelitian (Pendidikan Pendekatan Kuantitatif, Kualitatif, dan $R$ \& D). Bandung: Alfabeta. 
Suprijono, A. (2009). Cooperative Learning Teori dan Aplikasi Psikem. Yogyakarta: Pustaka Pelajar.

Tiro. (2015). Dasar-Dasar Statistika Edisi Ketiga. Makassar: Andira Publisher.

Yunus, S. R., Sudarto, \& Takdir, A. (2018). Pengaruh Model Pembelajaran Kooperatif Tipe Make A Match Terhadap Hasil Belajar Peserta Didik Kelas VII SMP Negeri 4 Kahu (Materi Pokok Ekosistem). JIT Vol 1. No 2. 